[Draft version of paper published as Charney, Michael W. (2011) 'Literary Culture on the Burma-Manipur Frontier in the Eighteenth and Nineteenth Centuries.' The Medieval History Journal, 14 (2). pp. 159-181]

\title{
Literary Culture on the Burma-Manipur Frontier in the Eighteenth and Nineteenth Centuries
}

\section{By}

\section{Michael W. Charney ${ }^{1}$}

(School of Oriental and African Studies)

How far literary culture in history can be examined depends upon collections of source material that is often less generous to the periphery than to the political center. It is true that the Orientalism debate has made scholars more sensitive to non-Western voices and Subaltern Studies has raised interest among historians in the local and the everyday. $^{2}$ Nevertheless, there has been less concern for locating and listening to voices outside of the political center. Literary history, outside of Europe at least, is still located in dynastic or regnal space, authors slotted into particular reigns that are rendered meaningful in a literary or cultural sense by particularly significant works,

\footnotetext{
${ }^{1}$ The author would like to thank Dr. Atsuko Naono (Warwick) and an anonymous referee for their helpful comments and suggestions on an earlier draft, Indrani Chatterjee (Rutgers) and Ramya Sreenivasan (SUNY Buffalo) for organizing the panel at the Association for Asian Studies Annual Meeting (2009) at which that draft was presented and for related discussion there, and Professor Victor B. Lieberman (Michigan) for helpful discussions in other contexts on some of the themes discussed in the present article.

${ }^{2}$ Sheldon Pollock, Literary Cultures in History: Reconstructions from South Asia (Berkeley: University of California Press, 2003): 12-13.
} 
while the regional identity of important elements of literary culture is generally ignored. ${ }^{3}$ Nevertheless, literary history also presents an intersection of the personal life histories of the authors and hence can thus incorporate biographical details that lend us hints of a broader world of people, places, and ideas that together form literary culture, however much their details escape or are hidden in this interstitial space by the state-centered narratives. Additionally, in Burma, a strong biographical tradition that probably stems from the importance in society of monasticism and driven by the demonstration of the accrual of merit by important monks has provided a model for indigenous scholars of literati that has produced highly detailed accounts of major writers, although at the sacrifice of very little detail on their writings save for the titles of major works. ${ }^{4}$ Strengthened by such detailed biography, a simultaneously broader and yet nuanced approach to literary culture is relevant to everything outside of the political center, but perhaps especially to those areas most distant from it, the subject of this article, borderlands. By heeding the call of scholars of borderlands to reverse the examination of border studies from the "view of the center" to "a view from the periphery," we find cultures that can complicate the state-centered narrative of literary history.

Our work would seem to be that much easier in the relatively few cases in which the literary culture of the periphery first becomes that of the center and then of a national imaginary, allowing us an unusually privileged glimpse of frontier

\footnotetext{
${ }^{3}$ See, for example, Pe Maung Tin, Myanma Sa-pei Thamaing (Rangoon: Thudhammawaddy Press, 1995).

${ }^{4}$ See, for example, U Ba Thein, “A Dictionary of Burmese Authors," Journal of the Burma Research Society 10.3 (1920): 120-154.

${ }^{5}$ Michiel Baud \& Willem van Schendel, “Toward a Comparative history of Borderlands," Journal of World History 8.2 (Fall 1997): 212.
} 
perspectives on literary culture. One such case, the focus of this article, is that of the monks and lay literati of Konbaung Burma's Sudhamma Reformation. It is difficult to give a precise starting point for this period although it was in full force during the 1790s and first decade of the nineteenth century. It witnessed the rise of a regional clique of monastic and lay literati, who for convenience will be referred to here as the Chindwin scholars, from the frontier with Manipur along the Chindwin River to the commanding positions in Burma's monastic hierarchy, state ministerial echelons, and royal army. The Chindwin scholars admittedly owed some of their continuing influence to factors that had little or nothing to do with the control of literature per se. Their potential importance to the state owed much to changing demographic and economic circumstances that favored the Lower Chindwin. Further, their movement from the frontier to the royal court was also aided by the fact that the princely appanage of the new king, Bodawhpaya (r. 1782-1819), was located on the Chindwin and when he came to the court, he brought his locally recruited entourage with him. Afterward, these men remained heavily connected through marriage and birth with the royal service communities in the Chindwin from whom were drawn the main corps of the royal army. The comprehensiveness of their domination over state institutions, however, ensured that they exercised considerable influence over the king himself who depended upon them as much as vice versa. ${ }^{6}$

These Chindwin scholars can be understood in two ways relative to literary culture, overlapping but not confined by the world of written texts. First, as members

\footnotetext{
${ }^{6}$ The developments are examined in Michael W. Charney, Powerful Learning: Buddhist Literati and the Throne in Burma's Last Dynasty, 1752-1885 (Ann Arbor: University of Michigan Centers for South and Southeast Asian Studies, 2006).
} 
of a Buddhist textual community, ${ }^{7}$ the monastics among them had privileged claims to authority over religious texts and thus claims to authority over religious knowledge which they sought to strengthen by cultivating their command of texts. On occasion they demonstrated their authority over religious texts and knowledge by their success in presenting their monastic competitors as sham monks in monastic debates before the court and elsewhere. In seeming irony, they defeated monastic opponents in part by demeaning the oral transmission of texts from teacher to students amongst their competitors while attracting royal support through their own oral recitation of the Pali canon, demonstrating in part that there is more to literary culture than things written. With the king's cooperation, Chindwin monks launched the Reformation, reforming the religion and eliminating rival monastic sects, making them the most senior and powerful of monks in a unified monastic order. Having persecuted and defrocked the their rivals and establishing themselves as the orthodox sect, they remained the only sect recognized by the state until the mid-nineteenth century.

From local perspectives and the activities and writings of these Chindwin scholars, it is clear that Chindwin scholars were also part of another broader intellectual world and their scholarly network, at least in certain contexts, was open enough to include as well non-Buddhist peoples and cultures along the Chindwin area. In particular, Manipuri Brahmins played a significant role in shaping the perspectives of and cooperating in the literary activities of Chindwin-based Buddhist scholars and laypeople. Nevertheless, the narrative structures of Burmese histories left

\footnotetext{
${ }^{7}$ I adapt here the use of the term to reflect the orientation of lay and monastic individuals to the interpretation of a shared set of oral or written texts as put forward in Anne M. Blackburn, Buddhist Learning and Textual Practice in Eighteenth-Century Lankan Monastic Culture (Princeton: Princeton University Press, 2001): 12.
} 
behind by the chief ideologues of the Sudhamma Reformation worked to limit reference to this broader scholarly network, to hide the local nature of the literate culture of which they and the Brahmins were a part, and indeed to hide their activities at the court generally behind the images of orthodox Buddhism centred on linkages with Sri Lanka and a strong court under a traditional, powerful dhamma-raja. This article attempts to ferret out another story, one of a local literary culture and its participants on the Burma-Manipur frontier, by re-reading some of the state-centered sources left by the Chindwin scholars, Manipuri chronicles, local Chindwin texts, and other sources.

It may seem likely that literary culture would be more susceptible to political control because all Southeast Asian writers, viewed through the prism of older scholarship on local intellectual history, were dependent on royal patronage. Hence, they wrote for the court, lived in the court, and, unless they did something unbecoming and were banished, the texts they wrote would contribute to a permanent corpus of court literature kept in the royal library until, of course, the British or some other European power came to drag these texts away to collections in the metropole. Scholars of precolonial Southeast Asian history have overemphasized the agency of the king, or instead assume that the state and its wings reflected solely the will of the ruler. By identifying the king or "the court" in the singular as the primary agent of change, conventional historiography on Burma (and Southeast Asia) has compressed knowledge production into an uncomplicated process of king-directed action. In this way, the premodern Burmese state as the arm of the king and the production of central histories, religious texts, and other literature has been taken simply as a royal project. As a result, the acquisition of Sanskrit texts has been conventionally attributed to the king's political designs on India. His efforts to use missions to 
acquire Sanskrit texts from India were taken merely as cover for a design to form an alliance of disenchanted Indian rulers to oust the British from India. ${ }^{8}$

In recent decades, more literature has come to light and creative hands have been located in the shadowy outlands of early modern states, at work without and sometimes against the royal court. Patrons could be local and elite as well as royal. We should also note that our understanding of the relationship between monastics and lay scholars is much richer today and we may include the world of monastic libraries and the monks who maintained and accessed them in a greater world of literary culture. Again, the court did not monopolize this world. The existence of texts, biographies of writers and monks, and other records that reflect from the center on rural areas demonstrates a broader literary culture outside of the royal capital than state sources normally admit.

Regardless of its failure to monopolize literary culture, state sources were eventually able to dominate writing about it. In the case of Burma, the Chindwin scholars from the frontier with Manipur had an enormous impact in shaping the texts, histories, and other works, through which Burmese history is interpreted. Because their impact occurred so late in the precolonial period, however, their histories were later cemented in place by colonial-era scholars, Europeans and Burmese alike, as handbooks for defining "old Burma." This also meant that certain aspects of the

\footnotetext{
${ }^{8}$ Mabel Bode, The Pali Literature of Burma (Rangoon: Burma Research Society, 1909): 77. This is not to say, however, that such a design was not there. Indeed, there is one royal order from 1813 that indicates that Bodawhpaya was preparing for an invasion of East India Company territory (the edict refers literally to Mazzimadesa or India). Than Tun (ed.), Royal Orders of Burma, A.D. 1598-1885 (Kyoto: Kyoto University Centre for Southeast Asian Studies, 1985): [royal edict dated 11 April 1813], 7.306. However, this intention was not the exclusive goal of engagement with Sanskrit texts or their acquisition, which preceded this momentary fit of fancy of the king by years.
} 
Sudhamma Reformation project, including representations of an all powerful throne, that were emphasized in their histories were accepted by later scholars. These scholars were thus blinded to the internal workings of the court and knowledge communities, flexible boundaries between the world of the court and of the village, and the weak and ever-changing imperial traditions that sustained the court up to that time.

Scholars from the Chindwin in effect buried evidence of the history of literary culture in the Chindwin border zone. Some documents, even Burmese ones, indicate substantial activity not to mention that the Chindwin elite came to dominate the court from the 1780s. But what was happening in the Chindwin area itself during the high period of Manipuri-Burmese interaction and confrontation, the seventeenth and eighteenth centuries, for example, has been blotted out. For example, the Burmese chronicles produced from the late 1820s tell us a great deal about Manipuri campaigns in the 1730s down the Mu River further east, but on their testimony one would be surprised to know that the Manipuri ruler Gharib Newaz (r. 1709-1748) was just as well known locally for his campaigns down the Chindwin and conquest of villages along its banks. ${ }^{9}$ These conquests the Burmese chronicles composed by the Chindwin scholars do not record. Thus, we have to rely on an uneven assortment of materials to reconstruct the literary culture during this period, in particular by relying upon Manipuri chronicles.

The purpose of Chindwin scholars in suppressing information about their home region was to prevent complications for their own and the state's political and religious projects and demonstrates why attempting to understand the history of literary culture requires keeping one's eyes fixed as much on the political (and

\footnotetext{
${ }^{9}$ R. B. Pemberton, "Journey from Munipoor to Ava, and from thence across the Yooma Mountain to Arracan," Journal of the Burma Research Society 43.2 (December 1960): 23.
} 
economic and social) context as on the literati and the literature. One potential complication, for example, was the relevance of information about the Chindwin, which as a border zone would necessarily entail the possibilities of boundary issues, to the resolution of territorial disputes after the First Anglo-Burmese War (18241826). In the years following this war, negotiations took place between the British victors and the Burmese court over determining what territory along the Chindwin, the traditional northwestern frontier of Burma and southeastern frontier of Manipur, was historically Manipuri and what was Burmese. The awareness of this political context heavily influenced the production of Burmese state histories during the period. Since these negotiations often rested on extracts from the chronicles about conquests of local places in the area, the compilers of the state histories, the first major one being produced in the late 1820 s, are almost completely silent about the Chindwin area except for references to the grand Burmese conquest of Manipur in the late $1750 \mathrm{~s}$. This silence is almost certainly purposeful and strategic and in this way, the politics of the time influenced how scholars of the time, at least those involved in state politics, as were the Chindwin scholars, shaped the way they wrote about themselves, the country, and their shared history. Although space does not permit a full exegesis of their writings, Chindwin monastics who wrote histories of the Religion during the period of their dominance in the religious affairs of the kingdom were no less strategic in their handling of details of religious events in the history of the Chindwin zone, again virtually skipping the area entirely. ${ }^{10}$ It is this need to be

\footnotetext{
${ }^{10}$ See, for example, Maha-dama-thin-gyan, Tha-thana-lin-ga-ya sa-dan (Rangoon: Hanthawaddy Press, 1956) and Bimala Churn Law (tr.), The History of the Buddha's Religion (Sasanavamsa) (London: Luzac \& Co., 1952). For one of the few tha-thana-win from the period that were written by allies of the Chindwin scholars and do shed a little more light on the activities of the Chindwin scholars, see Mei-hti hsaya-daw, Vamsa Dipani (Rangoon: Hanthawaddy Press, 1966) as well as its
} 
flexible with the past to suit the ever-changing present, James Scott has argued, that contributed to the choice of orality over literacy amongst highland peoples in Southeast Asia. ${ }^{11}$ Similarly, it can be asserted that silence rather than orality or nonliteracy in the present case maximized this flexibility.

How far back the silence introduced by the Chindwin scholars goes back is unclear. Prior to the seventeenth century, it would appear that neither the Manipuri nor the Burmese courts exercised much political control at all over much of the Chindwin River. The Manipuri court sources do not record very much about the Chindwin during these centuries either until the early seventeenth century. Similarly, if we relied on Burmese state sources alone, we would note that from the early thirteenth century, during the Pagan period, only the southernmost extremities of the Chindwin are mentioned. ${ }^{12}$ These references are also largely made to monastic establishments in the area along the lower stretch of the river and these were forestdwelling monasteries on the frontiers, ${ }^{13}$ which would seem to indicate that Pagan's authority, and hence Burma as equated with Pagan, did not stretch very further

translation and excellent analysis in Patrick Arthur Pranke, "Treatise on the Lineage of Elders (Vamsadipani): Monastic Reform and the Writing of Buddhist History in Eighteenth-Century Burma" (Ph.D. dissertation: University of Michigan, 2004).

${ }^{11}$ While disagreeing with Scott about whether this is a conscious choice, the present author supports the point in terms of the persistence of orality over literacy. For Scott's argument, see James C. Scott, The Art of Not Being Governed: An Anarchist History of Upland Southeast Asia (New Haven: Yale University Press, 2009): 220-237.

${ }^{12}$ G. H. Luce, "Chin Hills_-Linguistic (Dec. 1954)—University Project," Journal of the Burma Research Society 42.1 (1959): 25.

${ }^{13}$ Than Tun, "Religion in Burma, A. D. 1000-1300," Journal of the Burma Research Society 42.2 (December 1959): 68. 
northward, perhaps no further than Monywa. ${ }^{14}$ Indeed, on such evidence G. H. Luce once argued that it was the Shans and not the Burmans who pushed the Chins out of the rest of the Chindwin River area. ${ }^{15}$ One would almost have to rely upon agricultural data to know that Burmese cultivators had expanded into the Lower Chindwin, although even here it is clear that Burmese settlement may not have extended very far into the middle or upper reaches of the river until the sixteenth century. ${ }^{16}$ There are also local, originally oral perhaps, traditions, of important monks with what are taken as Burmese names who were prominent scholars in villages as far north as Maungdaung, indicating that settlement patterns, from a local perspective, had not changed very much from the Pagan period (tenth to early fourteenth centuries) to the present. ${ }^{17}$ These beliefs may be incorrect, but do demonstrate that local perspectives on the Chindwin zone and its history differ dramatically from what is perceivable through (but not at the time perceived by the authors of) state sources derived from the former royal center.

From the mid-seventeenth century and especially the first half of the eighteenth century, exchanges between the Manipuri and Burmese royal courts and Manipuri and Burmese activity in the Lower Chindwin increased. Much of the activity recorded in the chronicles of either or both was diplomatic or otherwise involved peaceful exchanges between royal cultures, but little attention to the

\footnotetext{
${ }^{14}$ Luce, "Chin Hills--Linguistic Tour," 26.

${ }^{15}$ G. H. Luce, "Sources of Early Burma History," in C. D. Cowan \& O. W. Wolters (eds.), Southeast Asian History and Historiography: Essays Presented to D. G. E. Hall (Ithaca: Cornell University Press, 1976): 35 .

${ }^{16}$ Victor B. Lieberman, Strange Parallels: Southeast Asia in global context, c 800-1830 (Cambridge: Cambridge University Press, 2003): 108, 207.

${ }^{17}$ U Thu-da-sana, Maungdaung Youb-loun-paw-li-ka (Yangon: Yei-mya-lun sa-bei, 1998): 40.
} 
Chindwin artery between them. Much of their interaction, however, was hostile, beginning with a Burmese attack against Manipur in 1648 that was successfully repulsed, followed by another Burmese attack in $1651 .{ }^{18}$ Warfare between the two kingdoms culminated with the Burmese king, Alaunghpaya's (r. 1752-1760) campaign against Manipur in 1758-9 to bring that kingdom, and the Chindwin along with it, under Burmese control. From Alaunghpaya's campaign, already strong cultural flows from Manipur into the Chindwin Valley (as well as the royal city) dramatically increased. ${ }^{19}$ After his victory, Alaunghpaya deported thousands of Manipuri boatmen, silversmiths, and silk-weavers to the royal capital area. These people, with later contingents of Manipuri deportees, came to form a significant segment of the population of the Burmese royal city as it moved from one site to another. There, they formed substantial colonies of artisans, cultivators, cavalry, and other types of royal servicemen, and Manipuris formed whole villages and continued to communicate in Manipuri as well as in Burmese. ${ }^{20}$ The importance of this resettlement for our purposes here is not the movement of Manipuris from one political center to another. Rather, the positioning of Manipuris at two political centers encouraged increased traffic that moved mainly through the Chindwin

\footnotetext{
${ }^{18}$ Parratt (tr.), The Court Chronicle of the Kings of Manipur, 84, 85, 116.

19 Victor B. Lieberman, Burmese Administrative Cycles: Anarchy and Conquest, c. 1580-1760 (Princeton: Princeton University Press, 1984): 265; an earlier campaign in 1755-56 was a brief affair involving a battle at Tammu, and a Burmese withdrawal thereafter. R. K. Jhalajit Singh, A Short History of Manipur, $2^{\text {nd }}$ rev. ed. (Imphal: n.d., 1992): 176.

${ }^{20}$ R. K. Jhalajit Singh, A Short History of Manipur, $2^{\text {nd }}$ rev. ed. (Imphal: n.d., 1992): 177; Michael Symes, Account of an Embassy to Ava (London: Bulmer, 1800): 275, 288, 318-319, 360; John Crawfurd, Journal of an Embassy From the Governor-General of India to the Court of Ava in the Year 1827, (London: Henry Colburn, 1829): 126, 283; Pemberton, “Journey from Munipoore to Ava,” 50.
} 
corridor that sat between them. Between these two poles, the royal courts, the Chindwin appears as a transborder region culturally not completely dominated by one or the other, certainly by neither of the royal courts. The Chindwin area remained ethnically diverse, towns and other places known by different names by Burmese, Manipuris, and other groups, such as the Shan and Kadu. ${ }^{21}$

In the eighteenth century, the Burmese and Manipuri courts both attempted to mark out the division of their territory in the area using both the river, which was held sacred by the Manipuris at least, and temples which would seem to indicate a religious border. During Gharib Newaz's reign, the newly built Kowmawdaw Pagoda was established as the dividing marker between the two realms, as explained in an inscription left to record this function. Later, Alaunghpaya would also mark out the boundary with stones and other pagodas. In parts of the river valley, however, the Chindwin River and the temples marked a political or revenue boundary only in practice. People made choices (or had that choice made for them by Burmese and Manipuri expeditions) on which side of the river to live on the basis of where local revenue demands were greater or lesser or royal control more or less onerous. This often meant that Manipuris and Burmese lived on both sides of the river (the Chindwin) and the temples dividing Burmese and Manipuri territory. Decisions were not made on the basis of cultural, religious, or ethnic considerations; they did not have to be, for the river as a political boundary did not displace the river as a zone of cultural and religious interaction. ${ }^{22}$ Pagodas and temples in the region, however, were attractive rather than divisive. The local sponsors of and participants in temple fairs and religious feasts, and other events, for example, were drawn from throughout local

\footnotetext{
${ }^{21}$ Pemberton, "Journey from Munipoore to Ava," 14, 27, 44, 48.

${ }^{22}$ Ibid., 14, 23, 24.
} 
populations not from within religiously encapsulated communities. Through fairs and feasting, such religious structures represented opportunities for communication of ideas and the sharing of material culture amongst communities. We have numerous examples of trans-ethnic interaction at the social, religious, and literary level, including, for example, Kadus inviting Burmese to a feast centered on the slaughter of a buffalo marking the establishment of a pagoda. ${ }^{23}$ Europeans would later misunderstand the shared material culture of the region solely in terms of Burman political hegemony, in other words as evidence of Burmanization, one Western visitor even observing that the Manipuris deported to the royal capital were "Burmans in every thing but origin." 24

More importantly, sharing included literature and we can learn something about local literary culture indirectly from examining the perspectives of the men who came from this region during the seventeenth and eighteenth centuries. Many of the texts circulating in this frontier area moved across communities into each other's libraries. The Manipuris, for example, were interested in the historical texts of the various populations of the Chindwin and at least Shan history could be found in Manipuri translation, just as Manipuri Brahmins who sought to access particular old Manipuri books sometimes had to seek them in the libraries of important Burmese ministers from the Chindwin. Even after they came to dominate the Burmese royal center Chindwin monks depended upon the aid of Brahmins from Manipur and Hindu

\footnotetext{
${ }^{23}$ Ibid., 14.

${ }^{24}$ R. B. Pemberton, "Abstract of the Journal of a Route Travelled by Captain S. F. Hannay, of the 40th Regiment, Native Infantry, in 1835-36, from the Capital of Ava to the Amber Mines of the Hukong Valley on the South-east Frontier of Assam," SOAS Bulletin of Burma Research 3.1 (Spring 2005): 214.
} 
ascetics in middle Chindwin townships such as Kanni for help with the Sanskrit language per se or with Sanskrit texts. ${ }^{25}$

Importantly, some of the mediation of literary culture among the Chindwin scholars was through religion. Increased Manipuri-Burmese interaction led, for example, to the employment in 1706 of a Burmese architect to build a Burmese style temple (for the Burmese this would have been interpreted as a pagoda) for Kali. However, a major new religious force came with the Hinduization of the Manipuri court, and then moved through the Chindwin and reached all the way to the Burmese court at Ava. In the early decades of the eighteenth century, Brahmin priests were already moving back and forth between the Burmese and Manipuri royal courts in the early eighteenth century.

The real energy in changing society and culture in Manipur began in 1717 when Manipuri ruler Gharib Newaz adopted the Vaishnavite tradition of Hinduism. From 1722, Gharib Newaz, guided by his new guru Shanti Das, launched religious reform directed at eradicating local gods and establishing Hinduism more broadly as the religion of the land. This included a purge of all existing Manipuri (Meetei) language books, which were declared ritually impure and destroyed, to be replaced by new books written in Bengali script. ${ }^{26}$ The revolutionary impact on Manipuri society that resulted is probably best summed up in Victor B. Lieberman's assessment that the "brahmanically sanctioned changes that Gharib Newaz introduced ... inspired the Manipuris with a vast energy and missionary dynamism. ${ }^{, 27}$ It is also possible that this

${ }^{25}$ Amei-daw-pyei (Mandalay: Zambu-meitswei Press, 1961): 1.90; Pemberton, “Journey from Munipoore to Ava," 48, 50.

${ }^{26}$ Parratt (tr.), The Court Chronicle of the Kings of Manipur, 118, 119, 126, 141; Gangmumei Kabui, History of Manipur (New Delhi: National Publishing House, 1991): 1.252-253.

${ }^{27}$ Lieberman, Burmese Administrative Cycles, 209. 
missionary dynamism influenced Chindwin Buddhist monastics and the young prince who later became King Bodawhpaya of Burma and thus may provide an example of the orientation between literary culture and religious culture moving across communities, although other factors, such as longstanding disputes regarding the value of physically distancing oneself for meditative purposes from the everyday world and other doctrinal disputes over interpretation of the Vinaya would also have been at work in the latter case. Nevertheless, Manipuri Hindu zeal may have provided a model for Buddhist monastics in the Chindwin to follow.

The impact on Manipur of these changes can be overestimated, but the affect they had on the Lower Chindwin may have been dramatic in more tangible ways. According to some oral traditions, however, when the books were piled up to be burned, some books proved to be immune to the fire and flew off to different parts of the kingdom, a certain indication, along with the continued existence of reportedly burned manuscripts of the time today, that many texts were not really destroyed but hidden. ${ }^{28}$ More than anything else, these activities likely decentralized the distribution of Manipuri literature. Even without this event, Manipur was already a significant route for the introduction of Sanskrit works into Burma, as Sanskrit scholars have pointed out. Although the Simhala-niti spread to Burma by sea from Southern India, for example, other Sanskrit-based niti-texts came through northern India, probably brought by Manipuri Brahmins. $^{29}$

Beneath the veneer provided in the chronicles of the role of the king in directing these changes in one direction, there was a good deal of shifting around in

\footnotetext{
${ }^{28}$ Kabui, History of Manipur, 255.

${ }^{29}$ Ludwik Sternbach, “Indian Wisdom and Its Spread Beyond India." Journal of the American Oriental Society 101.1 (March 1981): 113.
} 
royal behavior. Although Shanti Das remained influential throughout much of Gharib Newaz's reign after the latter converted, the Manipuri ruler turned against the Brahmins of the guru several times, just as on several occasions, he also purged the guru's sect's sectarian rivals. In one case, the king, with the support of the guru, even stepped in on a dispute on the side of pre-Brahmanic Manipuri astrologers. In this case, one Brahmin family, who were teaching astrology to the Manipuris were ordered to stop doing so in 1729 since this was something that proper Brahmins should not do. At this, the Manipuri chronicle records, most of the Brahmins then in Manipur decided to abandon Manipur for the Burmese court but were caught in the Chindwin and forced to return. ${ }^{30}$ This was something that probably happened each time the court turned on one sect or another leading perhaps to successive groups of Brahmins moving out to the Chindwin frontier, as far from the reach of the Manipuri court as possible.

The reshaping of Manipuri culture and religion under Gharib Newaz was pervasive and saw Manipuri gods eradicated, Manipuri festivals equated with Hindu festivals, fictive lineages for important families drawn back to figures in the Mahabharata, the imposition of Hindu dietary restrictions including punishment for eating beef, and the division of Manipuri society into castes. ${ }^{31}$ This rapid transformation of Manipuri society was intended to be extended over Burma in the same way. The guru behind all of this, Shanti Das, left the Manipuri court for the Burmese royal court in August 1733. According the Manipuri sources, Shanti Das returned to Manipur in November/December 1733, because he had been denied entry

\footnotetext{
${ }^{30}$ Parratt (tr.), The Court Chronicle of the Kings of Manipur, 137.

${ }^{31}$ Kabui, History of Manipur, 255-259.
} 
into the Burmese royal court. ${ }^{32}$ Gharib Newaz accompanied by Shanti Das gathered an army and, headed by the flag of Hanuman, took it against the royal capital of Burma, only to find his passage blocked by the Irrawaddy River, which the Manipuri cavalry were unable to cross. Shanti Das is also said to have encouraged the Manipuri attack by instructing the Manipuris that by drinking and washing themselves with water from the Irrawaddy River, they would completely cleanse themselves of misfortune and danger. The guru set out again in 1743 officially to negotiate the provision of a Manipuri princess to the Konbaung king. However, the Manipur court chronicle implies he had set out to conquer Ava again. ${ }^{33}$ Further, according to Lower Chindwin authors writing in the late 1820s, Shanti Das wanted to establish Hinduism ("our way of thinking") in the mind of "the king who lives in Ava." 34 There is thus little doubt that Shanti Das had major plans for the Burmese court, especially since his large entourage consisted of five hundred of his disciples, including Brahmin priests. The Hindu teacher, however, fell ill and died about a month later. ${ }^{35}$

If there had been any real chance of a conversion of Burma to Hinduism this was doused by the end of the 1750 s. After the Burmese royal capital fell to the Mons in 1751, we hear little about the Lower Chindwin or Manipuri-Burmese interaction until the Burmese kingdom was fully restored in 1756. Manipur only seems to have been intent on waging war when Burma was strong and less inclined when it was weak. This may suggest that Manipur was freer to influence the Chindwin valley when the Burmese court was preoccupied with other matters. True to form, when

\footnotetext{
${ }^{32}$ Parratt (tr.), The Court Chronicle of the Kings of Manipur, 142, 143.

${ }^{33}$ Hman-nàn maha-ya-zawin-daw-gyì (Mandalay: Ko Hla Maung, 1955): 3.375; Kabui, History of Manipur, 1.259; Parratt (tr.), The Court Chronicle of the Kings of Manipur, 157.

${ }^{34}$ Hman-nàn maha-ya-zawin-daw-gyì, 3.381.

${ }^{35}$ Ibid.
} 
Burmese political power was more fully restored in 1756-1757, the Manipuri court returned to the offensive. In 1758, Manipuri forces tried twice to attack the Burmese capital, leading to a Burmese counteract in 1758 and then a campaign in 1759 that led to the fall of Manipur to the Burmese. ${ }^{36}$ From that point onwards, Burma became the dominant power in the Chindwin although by pushing the borders northward they ironically increased rather than decreased Burma's exposure to Manipuri influence, literary and otherwise.

Obscured by states and kings, however, were more local powers in the community and important behind Chindwin literary culture were women. This would not seem to be the case from the perspective of the Chindwin scholars once they came to the court. Indeed, there is a noticeable absence of women in the histories of the religion the men from this area produced in the late eighteenth century or the more broadly secular chronicles compiled soon after. In the court, as queens or ministers' wives, women were acted upon but rarely actors in these histories. Manipuri chronicles similarly include women as wives or, on occasion, as entertainers, such as a Burmese female gymnast who gave performances set to Burmese music for the benefit of the Manipuri court for several months before returning to Burma with her musical troupe. $^{37}$

Nevertheless, women in the Chindwin and Burma generally were an important part of the expansion of lay literacy that occurred over the course of the eighteenth century. ${ }^{38}$ We have little information on what literary consumption pattern among

\footnotetext{
${ }^{36}$ Parratt (tr.), The Court Chronicle of the Kings of Manipur, 171, 172.

${ }^{37}$ Saroj Nalini Aramban Parratt (tr.), The Court Chronicle of the Kings of Manipur: The Cheitharon Kumpapa (London: Routledge, 2005): 117.

${ }^{38}$ Charney, Powerful Learning, 54-58.
} 
women ensued in this century, except for complaints by Chindwin writers that it was unseemly for women to take up writing on what they perceived as silly topics with little skill. As U Toe complained in his late eighteenth century Ya-ma Yagan,

There are some women nowadays who - some way or other - posing as scholars, as authors, as savants, talking of 'Her works' and 'My works', put in the north what comes from the south, put and move the bowscargo to the stern. With their innuendoes and condemnations, with their loud-mouthed gabble, what a frighteningly learned lot they are! - not quite clever, not quite skilled... ${ }^{39}$

To be fair to Toe, he also complained about bullock drivers taking up writing and producing work unworthy of the court as well, but it is clear that there was at least some resentment of women attempting to contribute to what was until then a male literary culture.

Prominent in supporting at least the monastic contribution to local literary culture were wealthy local women. Despite the fact that the importance of women is a hallmark of Southeast Asia's regional cohesiveness and distinctness from its East and South Asian neighbors, the literature on Southeast Asian women in the precolonial period has yet to explain how this importance was reflected in religious and political patronage patterns. What we do know from evidence from the Chindwin in the seventeenth and eighteenth centuries and into the nineteenth century is that prominent women in the area sponsored bridges, temples, and monasteries, successfully backed their sons' emergence as monastic leaders, and patronized sculptors and other

\footnotetext{
${ }^{39}$ Hla Pe, "Letteratura Birmana," unpublished ms., 25.
} 
artisans. Many of these women were landowners or traders, and one Burmese woman was even an "entertainer" who sponsored the construction of a cane bridge over the river for local use in Manipur. ${ }^{40}$

More influential were land-owning women who derived their wealth from their husband's military or ministerial connections with the Burmese court. One such woman was Ma Kwe, the daughter of a local family in the village of Maungdaung in the interior of the middle portion of the Chindwin valley, who was wed to a Burmese soldier who had been given a great title by the Burmese king after the wars with the Mon. After her husband's death, she directed some of her wealth into religious patronage, donating land to the monastic order for the construction of the Myagundaung Pagoda, and sponsoring the construction of a forest monastery on the outskirts of the village. Her son, Nyana, became the monastery's most prominent pupil and eventually, at an unprecedented young age, became the prelate for the kingdom - a promotion made possible by connections through another former monk from the same village. While prelate, Nyana continued to cooperate with his mother in local patronage, his mother donating the land around the village and himself paying for the construction of new pagodas on it. Nyana would eventually donate to a new library also built near the pagoda nearly 8,600 volumes of the Pali canonical texts. ${ }^{41}$

Chindwin culture, however much it had emerged as a border culture, would eventually have importance that transcended their regional world. What was unique about the movement of the Chindwin scholars to the royal court from 1782 was that

\footnotetext{
${ }^{40}$ Pemberton, "Journey from Munipoore to Ava," 31; Parratt (tr.), The Court Chronicle of the Kings of Manipur, 117.

${ }^{41}$ R. R. Langham-Carter, "Four Notables of the Lower Chindwin," Journal of the Burma Research Society 30.1 (1940): 336-338.
} 
they carried what was essentially a local, transborder literary culture into a distant royal capital that then adopted it as its own and became the royal culture of Burma. One result of this move was that stories focusing on overland as opposed to simply maritime connections with India were introduced into Burmese chronicles where they had not been before. One example is that of Abhiraja, a descendant of Mahasammata, the first king of the world (and of the same clan that produced Gotama Buddha), who was said to have migrated into Burma over the mountains (presumably through Manipur) where he founded the first Burmese state at Tagaung and became the progenitor of the future royal lines of Burma. These events were now included in the new texts and chronicles where they had not been before in the previous major Burmese chronicle, U Kala's Maha-ya-zawin-gyi. Examined from a state perspective alone, the inclusion of the Abhiraja stories can be viewed as a way to grant universally relevant status to the new Burmese ruler Bodawhpaya. ${ }^{42}$

The inclusion in Burmese texts of this myth in the late eighteenth century, however, can also be viewed as an intersection of different interests, including more than the royal project just described. The story, for example, helped to reorient Burma's attention from its focus on the maritime world for royal and religious heritage to the northwest and the new group of monks and Brahmins who now came to the court, alongside a king from the same border region as well. At the same time, this myth, set in the distant past, did not offer details of more recent decades that would be dangerous in border negotiations with the British. This kind of mythic past, a migration of people from the Western frontier and from Manipur, would also have

\footnotetext{
${ }^{42}$ Indeed, this is the present author's understanding in Michael W. Charney, "Centralizing Historical Tradition in Precolonial Burma: The Abhiraja/Dhajaraja Myth in Early Kon-baung Historical Texts," South East Asia Research 10.2 (2002): 185-215.
} 
made sense to many in the extended Chindwin literary world, in particular those whose ancestors were dispersed from Manipur during the time of Gharib Newaz and Shanti Das. In other words, such a myth presented another past in which people from one cultural world came to change another, reflecting the realities of their present, the Burmese royal court's and monastic order's transformation by the Chindwin scholars.

The changes in the Burmese royal court, from 1782, were much more dramatic than simply the revision of history from a frontier perspective. Bodawhpaya had put men drawn from Chindwin in control of the monastic order and the machinery of the state, including state recordkeeping. Separately, these spheres of activity were powerful enough, but together they made the Chindwin men supreme in the realm of literary culture both lay and monastic. Chindwin men were thus enabled to launch a religious and cultural reformation that specifically sought the establishment of royal authority over both secular and religious knowledge, but in general imposed Chindwin literary culture on the royal court and its major clients throughout the kingdom. Rival monks and scholars went into hiding or lived in obscurity, perhaps to rise another day.

The historical narratives composed by the Chindwin scholars at the court are thus replete with demonstrations of their superior textual authority relative to their monastic rivals, especially those framed in binary terms, positive view of reliance on texts or negative view of oral teachings passed down from teacher to student as mentioned. The Chindwin monks' opponents lost monastic debates, we are told, because they relied upon false books presented to cover teachings passed down orally from teacher to student and all the errors that could be expected to have crept in by this manner of transmission of practice. In order to prevent such errors, the Chindwin monks, with the urging of the king, sought to identify a perfect set of the scriptures to 
use as the basis for carefully edited copies to be distributed to monasteries throughout the kingdom. ${ }^{43}$

The Chindwin monks also had now discredited works destroyed, a practice of new reformers already made familiar in the Chindwin by Shanti Das and Gharib Newaz. In the Chindwin they had been at the centre of the movement of people, texts, and ideas between Burma and Manipur. Responding perhaps to the influx of Brahmins, Shanti Das' efforts, or contradictions in histories of events, peoples, and the gods natural in the diversity of the area, they resolved their discontent with literary confusion through efforts to establish their authority not only over knowledge in the courtly centre but also over outlying areas, much like the one from whence they came. In doing so, the control mechanisms they established and the process by which they established them, came to blur the assumed divisions between courtly centre and social periphery.

Ultimately, the Chindwin scholars identified authoritative sources for all kinds of knowledge that could serve as the basis for verifying information included in texts. Only Pali texts would be considered authoritative for matters relating to the Religion. Proper Buddhist monks were forbidden by the monastic code to engage in such matters as astrology, crafts, and other "worldly" matters. This separation of worldly matters from the affairs of the Religion meant that Pali texts would not be used as authoritative texts for worldly knowledge. Instead, this left technical expertise in worldly matters to Brahmin priests who served, as one scholar observes, as the

\footnotetext{
${ }^{43}$ See Charney, Powerful Learning, $18-49$.
} 
"scientists of the court," especially in the handling of royal astrological demands. ${ }^{44}$ Brahmin priests from Manipur had already been active in the Burmese court in the early sixteenth century composing, in Pali, royal texts, such as the Rajaniti, in the royal capital on the basis of Sanskrit sources. This particular text would fit into a particular genre of Burmese court literature, dependent perhaps on this model, which record a wise minister's advice to the king on how to conduct his rule wisely. ${ }^{45}$ In the case of the Burmese court, this would include not only the Maniyadanabon, compiled in 1781 , but attributed to the early fifteenth century minister Min-yaza, as well as the Amei-daw-pyei, which was compiled later on the basis of Nyana's advice to Bodawhpaya. Interestingly, in both cases, the wise ministers (for Nyana became a secular minister after being defrocked) were rural men of great textual learning, Minyaza from the Lake Meiktila area in Central Burma, but Nyana, of course, from the Lower Chindwin.

In the early years of Bodawhpaya's reign, final authority regarding translation of Sanskrit texts into Burmese was left to Chindwin monks and layman such as Bodawhpaya's teacher Twin-thin, although the actual translation work may have been conducted by Brahmins working under them. ${ }^{46}$ In the next few years, however, the ritual functions and authority over interpreting Sanskrit texts were separated into different knowledge communities. What is most interesting about the new division of labor is how the Brahmins were divided relative to the Sanskrit literature. Some groups of Brahmins from different towns of Burma were now limited to certain

\footnotetext{
44 William J. Koenig, The Burmese Polity, 1752-1819: Politics, Administration, and Social Organization in the Early Konbaung Period (Ann Arbor: University of Michigan Center for South and Southeast Asian Studies, 1990): 91.

${ }^{45}$ Sternbach, "Indian Wisdom and its Spread Beyond India," 115.

${ }^{46}$ Than Tun (ed.), Royal Orders of Burma, [ROB 1 July 1783], 4.260.
} 
activities, such as conductors of rituals or foot massagers, while only those from the Chindwin area, the Manipuri Brahmins, were placed in charge of the interpretation of non-religious, "worldly" books (lawki sa-pei), which in effect were Sanskrit texts, ${ }^{47}$ a choice that seems to have reflected the Chindwin roots of the Sudhamma leadership. Possibly, the transformation of Manipuri Brahmin from sacral broker to assistant in the translation into Burmese of Sanskrit knowledge was a means of limiting the authority of this knowledge group to worldly knowledge as a form of disempowerment. Rather than serving the king directly, the Manipuri Brahmins who worked specifically on texts were now placed under the supervision of the Buddhist prelate, a Sanskrit specialist himself, symbolically placing the Brahmin from Manipur beneath the Buddhist monk from the Chindwin. But also by defining the texts of Brahmins as "worldly knowledge" in intellectual terms the Brahmins were not a threat to the position of the Buddhist monastic establishment, not just in the court, but also at the intersection of a Hindu and a Buddhist culture in the Chindwin borderland.

The result was the encouragement of a kind of Sanskritization of secular knowledge that would not have seemed strange to the court of Gharib Newaz and Shanti Das in the 1720 s. If Sanskrit texts were to be the authority for "worldly knowledge" for the new vernacular translations, then the next step would be to acquire as much Sanskrit literature as possible for translation into Burmese and to acquire these texts directly from the source-the Subcontinent. The number of Sanskrit texts imported by the royal court represented a large number of texts. Before Bodawhpaya's reign there had been a trickle of some sixty Sanskrit texts in the reign of Hsinbyushin, but for what purpose is unclear and we do not know with certainty if

\footnotetext{
${ }^{47}$ U Tin, Myan-ma-min Ok-chok-pon Sa-dan (Rangoon: Superintendent, Government Printing and Stationary, 1931-1933): 2.47-48.
} 
all of them came from Manipur. Under Bodawhpaya, according to William Koenig, at least 250 more were imported, mostly from India, and these were all translated into Burmese. $^{48}$

We have little information, however, about how many or what kinds of Sanskrit texts were available locally in the Chindwin, from whence the monastic leadership came. Ultimately, given the Chindwin rejection of earlier local Burmese copies of texts, whether Pali or Sanskrit, as error-ridden, hence the need for texts directly from either India or Sri Lanka, these probably would have been destroyed or otherwise forgotten. Since there is no single listing of all of these texts, the 236 titles listed by Than Tun will have to serve as an indication of the types of texts included under the category of "worldly knowledge": fifty-eight focused on astrology, fifty-six on grammar, twenty-five on medicine, twenty-three on logic, eight on law, and the remainder on miscellaneous topics, from dictionaries to treatises on elephants. ${ }^{49}$

After Bodawhpaya's reign, perhaps even during a period in the 1810 s when the king questioned his alliance with the monks among the Chindwin men at his court, the Sudhamma Reformation experienced a period of reversal, the king abandoning support for the Pali-Sanskrit division of labor. Even when important elements of the Reformation recommenced under his grandson and successor Bagyidaw (r. 18191837), things were no longer the same, it would seem, for the division of knowledge

\footnotetext{
${ }^{48}$ Nyana, however, refers to 253 Sanskrit texts imported in Bodawhpaya's reign, while Than Tun finds only 236 titles, but appears to have mistaken the list of texts brought back on one mission alone as a listing of all Sanskrit texts imported between 1786-1818. Than Tun, "The Influence of Occultism in Burmese History with Special Reference to Bodawpaya's Reign 1782-1819," Bulletin of the Burma Historical Commission 1.2 (1960): 131-132; Koenig, The Burmese Polity, 92; Charney, Powerful Learning, 45.

${ }^{49}$ These classifications are based on the list in Than Tun, "Influence of Occultism," 132-141.
} 
or at least in the division of labor established for its control. Manipuri Brahmins were once again called upon to perform court rituals, ${ }^{50}$ suggesting that their special place relative to the worldly texts may have ended. It was Chindwin monks and not Manipuri Brahmins who returned to the task of translating Sanskrit works into Pali. Indeed, one of the most well-known of Burma's four major Sanskrit-based niti texts, the Loka-niti, composed by the Brahmin Sannekgyaw, was paraphrased into Burmese during this period by the Buddhist monk, U Boke (1787-1842), who came from Nyana's neighborhood in the Lower Chindwin. ${ }^{51}$ In any event, scholars from the Chindwin remained important at the center.

The blinds presented by state-centered history make it very difficult to see people distant both figuratively and literally from the political center. In some cases, as with the Chindwin scholars examined here, they may not have wanted to have been seen at all. Nevertheless, understanding literary culture requires examining what we should not know as much as what we should and to look for it as much in the silences as in what has been said in the texts. This task would be impossible in conventional literary history or broader intellectual histories that examine the development and movement of styles and ideas, independently of the nitty-gritty of the real world of their authors and readers. In the present article, the "real world" was not the political center, but the periphery, in a transborder zone at the overlap of two states. One could be forgiven for not realizing this, given that the authors from this area were so intent on presenting themselves as an integral part of the political and cultural center of their world. Literary history has also not helped, being unkind to the notion of literary

\footnotetext{
${ }^{50}$ Pemberton, "Journey from Munipoore to Ava," 60.

${ }^{51}$ Ludwik Sternbach, “The Pali 'Lokaniti' and the Burmese 'Niti Kyan' and their Sources,” Bulletin of the School of Oriental and African Studies 26.2 (1963): 331.
} 
history not delimited by national boundaries. Chindwin literary culture, as colonial scholars and indigenous scholars who trained under them were convinced, was Burmese traditional literary culture, for they did not understand its origins or its former distance from the royal court. For their literary repute, the Chindwin scholars were fortunate that the Konbaung Dynasty ended so soon after their time, for it locked in place their work as the final precolonial, indigenous stamp on Burmese literary culture.

\section{Bibliography}

Amei-daw-pyei. 2 vols. Mandalay: Zambu-meitswei Press. 1961.

Ba Thein, U. "A Dictionary of Burmese Authors.” Journal of the Burma Research Society 10.3 (1920): $120-154$

Baud, Michiel \& Schendel, Willem van. "Toward a Comparative history of Borderlands." Journal of World History 8.2 (Fall 1997): 211-242.

Blackburn, Anne M. Buddhist Learning and Textual Practice in Eighteenth-Century Lankan Monastic Culture. Princeton: Princeton University Press. 2001.

Bode, Mabel. The Pali Literature of Burma. Rangoon: Burma Research Society. 1909.

Charney, Michael W. Powerful Learning: Buddhist Literati and the Throne in Burma's Last Dynasty, 1752-1885. Ann Arbor: University of Michigan Centers for South and Southeast Asian Studies. 2006.

. "Centralizing Historical Tradition in Precolonial Burma: The Abhiraja/Dhajaraja Myth in Early Kon-baung Historical Texts.” South East Asia Research 10.2 (2002): 185-215.

Crawfurd, John. Journal of an Embassy From the Governor-General of India to the Court of Ava in the Year 1827. London: Henry Colburn. 1829.

Hla Pe, U. "Letteratura Birmana.” Unpublished ms.

Hman-nàn maha-ya-zawin-daw-gyì. 3 vols. Mandalay: Ko Hla Maung. 1955.

Kabui, Gangmumei. History of Manipur. Volume I. New Delhi: National Publishing House. 1991. 
Koenig, William J. The Burmese Polity, 1752-1819: Politics, Administration, and Social Organization in the Early Konbaung Period. Ann Arbor: University of Michigan Center for South and Southeast Asian Studies. 1990.

Langham-Carter, R. R. "Four Notables of the Lower Chindwin." Journal of the Burma Research Society 30.1 (1940): 336-342.

Law, Bimala Churn (tr.). The History of the Buddha's Religion (Sasanavamsa). London: Luzac \& Co. 1952.

Lieberman, Victor B. Burmese Administrative Cycles: Anarchy and Conquest, c. 1580-1760. Princeton: Princeton University Press. 1984.

Strange Parallels: Southeast Asia in Global Context, c 800-1830. Cambridge: Cambridge University Press. 2003.

Luce, G. H. "Sources of Early Burma History." In C. D. Cowan \& O. W. Wolters (eds.), Southeast Asian History and Historiography: Essays Presented to D. G. E. Hall (Ithaca: Cornell University Press, 1976): 31-42. . "Chin Hills_-Linguistic (Dec. 1954)—University Project,” Journal of the Burma Research Society 42.1 (1959): 19-31.

Maha-dama-thin-gyan. Tha-thana-lin-ga-ya sa-dan. Rangoon: Hanthawaddy Press. 1956.

Mei-hti hsaya-daw. Vamsa Dipani. Rangoon: Hanthawaddy Press. 1966.

Parratt, Saroj Nalini Aramban (tr.). The Court Chronicle of the Kings of Manipur: The Cheitharon Kumpapa. London: Routledge. 2005. . The Religion of Manipur: Beliefs, Rituals and Historical Development. Calcutta: Firma KLM Private Limited. 1980.

Pe Maung Tin. Myanma Sa-pei Thamaing. Rangoon: Thudhammawaddy Press. 1995.

Pemberton, R. B. "Journey from Munipoor to Ava, and from thence across the Yooma Mountain to Arracan.” Journal of the Burma Research Society 43.2 (December 1960): 1-96. . "Abstract of the Journal of a Route Travelled by Captain S. F. Hannay, of the 40th Regiment, Native Infantry, in 1835-36, from the Capital of Ava to the Amber Mines of the Hukong Valley on the South-east Frontier of Assam." SOAS Bulletin of Burma Research 3.1 (Spring 2005): 197-227. 
Pollock, Sheldon. Literary Cultures in History: Reconstructions from South Asia. Berkeley: University of California Press. 2003.

Pranke, Patrick. "Bodawpaya's Madness: Monastic Accounts of King Bodawpaya's Conflict with the Burmese Sangha, Part One.” Journal of Burma Studies 12 (2008): 1-28.

. "Treatise on the Lineage of Elders (Vamsadipani): Monastic Reform and the Writing of Buddhist History in Eighteenth-Century Burma.” Ph.D. dissertation: University of Michigan. 2004.

Symes, Michael. Account of an Embassy to Ava. London: Bulmer. 1800.

Singh, R. K. Jhalajit. A Short History of Manipur. $2^{\text {nd }}$ rev. ed. Imphal: n.d., 1992.

Sternbach, Ludwik. "The Pali 'Lokaniti' and the Burmese 'Niti Kyan' and their Sources." Bulletin of the School of Oriental and African Studies 26.2 (1963): 329-345.

. "Indian Wisdom and Its Spread Beyond India." Journal of the American Oriental Society 101.1 (March 1981): 97-131.

Than Tun. "The Influence of Occultism in Burmese History with Special Reference to Bodawpaya's Reign 1782-1819.” Bulletin of the Burma Historical Commission 1.2 (1960): 117-145.

. "Religion in Burma, A.D. 1000-1300," Journal of the Burma Research Society 42 (December 1959): 47-69.

. "Mahakassapa and his Tradition." Journal of the Burma Research Society 42.2 (1959): 99118.

(ed.). The Royal Orders of Burma, A. D. 1598-1885. 10 vols. Kyoto: Centre for Southeast Asian Studies, Kyoto University. 1985.

Thu-da-sana, U. Maungdaung Youb-loun-paw-li-ka. Yangon: Yei-mya-lun sa-bei. 1998.

Tin, U. Myan-ma-min Ok-chok-pon sa-dan. 5 vols. Rangoon: Superintendent, Government Printing and Stationary. 1931-1933. 